\title{
Utilization of Bio-Syngas in Solid Oxide Fuel Cell Stacks: Effect of Hydrocarbon Reforming
}

\author{
Hyeondeok Jeong, ${ }^{1}$ Michael Hauser, ${ }^{2}$ Felix Fischer, $\oplus^{2}$ Maximilian Hauck, ${ }^{2}$ Sandra Lobe, ${ }^{1}$ \\ Roland Peters, ${ }^{3}$ Christian Lenser, ${ }^{1}$ Norbert H. Menzler, ${ }^{1, *, z}$ and Olivier Guillon ${ }^{1,4}$ \\ ${ }^{1}$ Forschungszentrum Jülich GmbH, Institute of Energy and Climate Research, Materials Synthesis and Processing, \\ 52425 Jülich, Germany \\ ${ }^{2}$ Technische Universität München, Chair of Energy Systems, 85748 Garching, Germany \\ ${ }^{3}$ Forschungszentrum Jülich GmbH, Institute of Energy and Climate Research, Electrochemical Process Engineering, \\ 52425 Jülich/Germany \\ ${ }^{4}$ Jülich Aachen Research Alliance: JARA-Energy, 52425 Jülich, Germany
}

\begin{abstract}
We report on state-of-the-art JÜLICH (Forschungszentrum Jülich) stack with anode-supported solid oxide fuel cells (AS-SOFCs) that have been tested in bio-syngas derived from wood pellets. The sulfur and chlorine were removed after gasification, but the tars were not reformed in the bio-syngas to study the influence of these tars on the degradation of SOFC stack. The total tar content during test was $3.5 \mathrm{~g} / \mathrm{Nm}^{3}$ including benzene, toluene, phenol, m-cresol, naphthalene, and minor traces of undefined tars. The test result shows considerable performance degradation in tar-contaminated syngas. Moreover, the test was stopped after 5 hours of operation due to an increase of the pressure drop in the stack. A post-test analysis was carried out, and heavy carbon deposition was found at the cell anode-support surface and the Ni mesh current collector. Carbon was identified by SEM as numerous carbon fibers. The change of support microstructure was also observed near and under the carbon deposition area, and the dusting of Ni metal was observed in the support and Ni mesh current collector.

(C) The Author(s) 2019. Published by ECS. This is an open access article distributed under the terms of the Creative Commons Attribution 4.0 License (CC BY, http://creativecommons.org/licenses/by/4.0/), which permits unrestricted reuse of the work in any medium, provided the original work is properly cited. [DOI: $10.1149 / 2.1191902 \mathrm{jes}]$

(cc) BY
\end{abstract}

Manuscript submitted November 20, 2018; revised manuscript received January 22, 2019. Published January 30, 2019.

Solid oxide fuel cell (SOFC), an energy conversion device that converts chemical energy into electricity, is a promising technology for the transition to renewable and clean energy sources. Recently, they have shown commercially applicable performance and stability. ${ }^{1}$ A planar SOFC stack run at Forschungszentrum Jülich (JÜLICH) shows the longest operation time reported so far $(93,000 \mathrm{~h})^{2,3}$ with $0.6 \% / 1000 \mathrm{~h}$ average voltage degradation rate overall, and a recent result with a 4 layer stack shows over $34,000 \mathrm{~h}$ operation with only $0.3 \% / 1000 \mathrm{~h}$ overall voltage degradation rate using $20 \%$ humidified hydrogen as fuel. ${ }^{2}$ Their initial operation performance was approximately $0.4 \mathrm{~W} / \mathrm{cm}^{2}\left(\sim 0.8 \mathrm{~V}\right.$ at $\left.0.5 \mathrm{~A} / \mathrm{cm}^{2}\right)$, which is high enough for scaling up to $5-20 \mathrm{~kW}$ system. ${ }^{2,4}$ SOFC power generation systems are receiving more attention due to their high energy conversion efficiency and low emission of greenhouse gases.

However, there are problems still to be overcome before a wide use of the SOFC systems can be achieved: the absence of a hydrogen infrastructure, relatively high manufacturing costs of the whole system (including balance-of-plant). In the case of hydrogen, which is currently the most preferred fuel, is mainly produced by reforming fossil fuels. ${ }^{5}$ Since fossil fuels are limited and emit greenhouse gases during the reforming process, ${ }^{6}$ it is in conflict with the aim of using SOFC systems to produce clean energy. There are alternative ways of hydrogen production, such as water splitting or electrolysis. However, these require an additional energy source such as wind or solar generators, so the cost is nowadays still more expensive than fossil fuel reforming. 6,7

An alternative fuel is biomass, which is renewable, easily produced, and carbon neutral. The gasified biomass fuel (bio-syngas) can be applied directly to SOFCs due to their high operating temperature $\left(650-950^{\circ} \mathrm{C}\right) .^{8-11}$ Therefore, a system of coupling a gasifier producing bio-syngas and SOFCs has been suggested by many authors with their simulation works, ${ }^{12-15}$ tested with simulated syngas ${ }^{16-20}$ and with actual bio-syngas. ${ }^{21-23}$ A system using actual bio-syngas needs an additional reformer for cleaning the bio-syngas because it includes impurities such as tars, ${ }^{16-20}$ sulfur, ${ }^{24-26}$ and phosphorus ${ }^{27,28}$ causing significant mechanical and electrochemical degradation. This additional reformer makes the system more complex and expensive. Moreover, the reformer also shows poisoning and degradation. ${ }^{29}$ Thus, internal reforming of the tar and sulfur in SOFCs with an alternative anode material would be more favorable.

In this study, wood-derived bio-syngas was applied to a JÜLICH state-of-the-art SOFC stack. The tests were performed at the Chair of Energy Systems at TUM. The bio-syngas went through the sulfur and chlorine cleaning process, but tar was left in the syngas to study the effect of tar in the stack test as a preliminary work of direct coupling of bio-syngas and SOFCs. We mainly report on the post-test characterization of the materials and structural changes of the cell after operation. More insights into the operation of the gasifier, the stack test rig and the fundamental electrochemical characterization will be published elsewhere.

\section{Experimental}

Cell and stack configuration.-A JÜLICH standard 4-layer stack was used in this study. ${ }^{2}$ The cells were commercially purchased (CeramTec GmbH, Germany). They consisted of a $\mathrm{Ni} / \mathrm{Y}_{0.058} \mathrm{Zr}_{0.942} \mathrm{O}_{1.971}$ (3YSZ) anode support, Ni/ $\mathrm{Y}_{0.148} \mathrm{Zr}_{0.852} \mathrm{O}_{1.926}$ (8YSZ) anode, 8YSZ electrolyte, $\mathrm{Gd}_{0.2} \mathrm{Ce}_{0.8} \mathrm{O}_{1.9}$ (20GDC) barrier, and $\mathrm{La}_{0.58} \mathrm{Sr}_{0.4} \mathrm{Co}_{0.2} \mathrm{Fe}_{0.8} \mathrm{O}_{3-\delta}$ (LSCF) cathode. The cells had a $100 \times 100$ $\mathrm{mm}^{2}$ support dimension and $90 \times 90 \mathrm{~mm}^{2}$ active cathode area. All interconnects, cell frames, top and bottom plates were based on Crofer $22 \mathrm{APU}^{30} \mathrm{~A} \mathrm{MnCo}_{1.9} \mathrm{Fe}_{0.1} \mathrm{O}_{4}$ (MCF) coating was applied on the interconnect surfaces facing the cathode side by atmospheric plasma spraying (APS) as a Cr-poisoning protection layer. ${ }^{31}$ For the contact between cell and interconnect, Ni mesh was used on the anode side, and a $\mathrm{LaMn}_{0.45} \mathrm{Co}_{0.35} \mathrm{Cu}_{0.2} \mathrm{O}_{3-\delta}$ ( $\mathrm{LCC} 10$ ) coating was applied directly on the cathode side of the cell by screen printing. Type $87 \mathrm{ZYBF}-$ 2 glass sealant was used for stack assembly ${ }^{32}$ and the entire stack was held at $850^{\circ} \mathrm{C}$ for $100 \mathrm{~h}$ to ensure glass crystallization and gastightness. The designation of cell and stack components is shown in Figure 1 as a schematic diagram with direction of fuel gas flow.

Stack test.-The wood pellet feedstock was $8 \mathrm{~mm}$ in diameter and 6-12 $\mathrm{mm}$ in length with low moisture and ash content. A bubbling fluidized bed was used for gasification of biomass via a vibrating feeding system from the top. The superheated steam was supplied as oxidant gas from bottom. The gasifier was heated up electrically with two separated heating zones for the fluidized bed $\left(790^{\circ} \mathrm{C}\right)$ and the freeboard $\left(600^{\circ} \mathrm{C}\right)$. In total 2 Liters of silica sand and 0.25 Liter of 


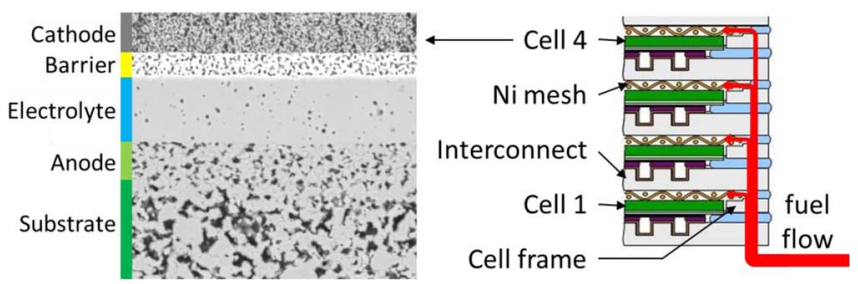

Figure 1. Cross sectional SEM image of reduced cell structure and schematic diagram of stack structure with fuel flow.

biomass char (from previous runs) were used as bed material. After the gasification, sulfur and chlorine were removed by ActiSorb S2 and ActiSorb $\mathrm{Cl} 2$ adsorbents (Clariant, Swiss). Still certain contents of hydrocarbon fuel such as $\mathrm{CH}_{4}, \mathrm{C}_{2}-\mathrm{C}_{5}$, and especially tars remained, so Ni-based catalyst was used for reforming of hydrocarbon fuels at $800^{\circ} \mathrm{C}$. The stack was operated with syngas after tar reforming during first $2 \mathrm{~h}$, and when a stable operating point was reached the tar cleaning was bypassed and the tar containing syngas was fed to the stack. The composition of fuel and tar content is presented in Table I.

The stack was operated in an oven at $715^{\circ} \mathrm{C}$ with temperature measurement in each interconnect and cell frame. Fuel gas and air are supplied from the bottom of the stack via an adapter plate. The test was carried out in galvanostatic operation mode with PLI 2106 controller (Höcherl \& Hackl GmbH, Germany) at $0.25 \mathrm{~A} / \mathrm{cm}^{2}$. Each cell voltage was measured and recorded individually using a 4-channel data logger (Onset Hobo) and the overall stack voltage was recorded via two rods made of Inconel and two sense cables. The current rods are screwed to the bottom and the top plate of the stack and the sense cables consist of platinum wires that are welded to the end plates and interconnects and extended by silver wires to the respective measurement devices. The pressure drops of fuel inlet and air outlet were measured, and the pressure drop of the entire stack was calculated by comparing inlet and outlet pressures.

Macro and microstructure analysis. - The microstructure of the cells was analyzed by scanning electron microscopy (SEM) using a Zeiss Gemini Ultra 55 electron microscope (Carl Zeiss NTS GmbH, Germany). The stack components were investigated in two different ways: surface and fractured cross-sectional images for morphology changes or surface carbon deposition, and polished cross sectional images for microstructural changes.

Raman spectra.-An inVia Raman Microscope (Renishaw, UK) was used for collecting Raman spectra using a $532 \mathrm{~nm}$ laser, a grating

Table I. The composition of fuel and tar content.

\begin{tabular}{ccccc} 
& & After gasifier & Clean-syngas & Tar-syngas \\
\hline $\mathrm{H}_{2}$ & $\mathrm{v}-\% \mathrm{db}^{*}$ & 23.9 & 37.0 & 26.9 \\
$\mathrm{CO}_{2}$ & $\mathrm{v}-\% \mathrm{db}$ & 11.3 & 11.6 & 14.1 \\
$\mathrm{CO}$ & $\mathrm{v}-\% \mathrm{db}$ & 8.7 & 9.8 & 7.3 \\
$\mathrm{CH}_{4}$ & $\mathrm{v}-\% \mathrm{db}$ & 3.6 & 0.2 & 3.7 \\
$\mathrm{C}_{2}-\mathrm{C}_{5}{ }^{* *}$ & $\mathrm{v}-\% \mathrm{db}$ & 0.9 & 0.0 & 0.9 \\
$\mathrm{~N}_{2}$ & $\mathrm{v}-\% \mathrm{db}$ & Bal. $(51.6)$ & Bal. $(41.4)$ & Bal. $(47.1)$ \\
$\mathrm{H}_{2} \mathrm{~S}$ & $\mathrm{ppm} \mathrm{v}_{\mathrm{db}}$ & 12.2 & 0.0 & 0.0 \\
Benzene & $\mathrm{g} / \mathrm{Nm}^{3} \mathrm{db}$ & 0.9 & 0 & 0.8 \\
Toluene & $\mathrm{g} / \mathrm{Nm}^{3} \mathrm{db}$ & 0.6 & 0 & 0.5 \\
Phenol & $\mathrm{g} / \mathrm{Nm}^{3} \mathrm{db}$ & 0.9 & 0 & 0.5 \\
m-Cresol & $\mathrm{g} / \mathrm{Nm}^{3} \mathrm{db}$ & 0.6 & 0 & 0.2 \\
Naphthalene & $\mathrm{g} / \mathrm{Nm}^{3} \mathrm{db}$ & 0.2 & 0 & 0.2 \\
Other tars & $\mathrm{g} / \mathrm{Nm}^{3} \mathrm{db}$ & 1.8 & 0 & 1.3 \\
$\mathrm{H}_{2} \mathrm{O}^{* *}$ & $\mathrm{v}^{*}{ }^{2}$ & $\sim 42.0$ & - & -
\end{tabular}

* dry basis.

** not measured, average value in similar condition.

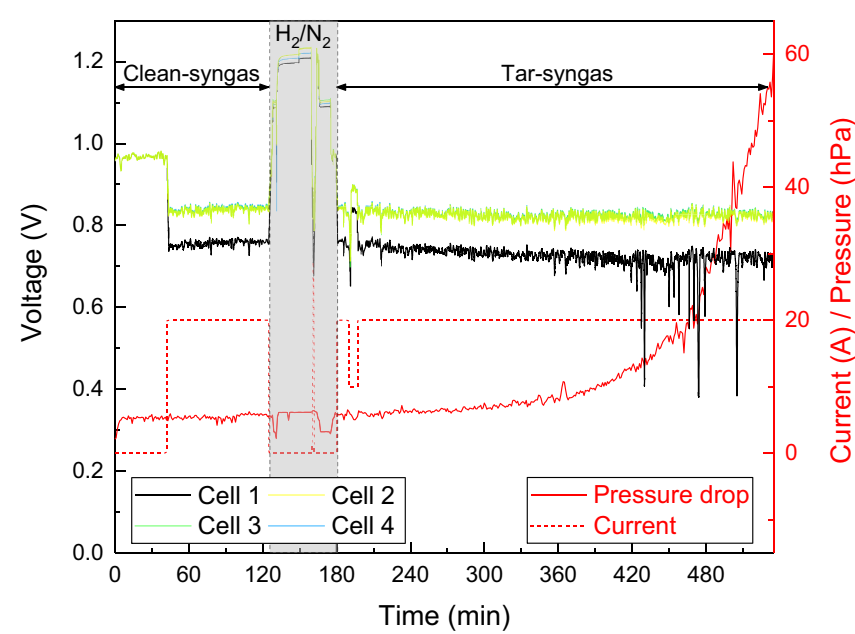

Figure 2. Stack test result with cleaned syngas (tar, sulfur, and chlorine removed) and tar-syngas (sulfur and chlorine removed) at $715^{\circ} \mathrm{C}$. Note: the voltage curves of cell 2 to 4 (yellow, green, and blue) overlap completely.

with 1800 lines/mm and a CCD Detector. A piece of cell was taken from the vicinity of the gas inlet and carbon mapping was carried out on the fractured cross section within an $90 \mu \mathrm{m}$ wide area and running from the electrolyte layer to the surface of the support. Step size for the cross section measurements was $1 \mu \mathrm{m}$. The laser power was set to $10 \%$ (about $2.5 \mathrm{~mW}$ ) and the exposure time was $10 \mathrm{~s}$. If necessary, the live track function (auto focus software solution) was applied.

To analyze collected carbon from the cell surface and the contacting Ni mesh, carbon powder was removed and subsequently Raman spectra were measured with a glass holder. The data was collected from 496 points (cell) and 656 points (Ni mesh), respectively with the same exposure time of $10 \mathrm{~s}$ but reduced laser power of $0.5 \%$.

Data processing for the cross section included cosmic ray removal and a background subtraction. The mappings were generated by direct least square analysis of the signal by using a carbon spectrum generated from anode side data collection. Cosmic ray removal and integration to normalized signal was also applied for the data of the collected carbon powder before averaging the different data points.

\section{Results}

Stack test results.-The stack test results are presented in Figure 2, showing voltage, current and the pressure drop across the stack as a function of time. The test was started with clean-syngas (bio-syngas with removed tar, sulfur, and chlorine). The open-circuit voltage $(\mathrm{OCV})$ was almost identical for all four cells $(0.97 \mathrm{~V})$ which is a lowered value by diluting of fuel with $\mathrm{N}_{2}, \mathrm{CO}_{2}$ and a higher steam fraction compared to the OCV value of $1.05 \mathrm{~V}$ under $20 \%$ humidified hydrogen at $700^{\circ} \mathrm{C}$. During operation at a current density of 0.25 $\mathrm{A} / \mathrm{cm}^{2}$, cell 1 shows a lower voltage $(0.75 \mathrm{~V})$ than the other three cells $(0.84 \mathrm{~V})$ during the test. This is a well-known feature of the JÜLICH stacks, ${ }^{33}$ but the reason is not fully understood yet. One possible reason is the cell 1 is located at the bottom position in the stack where the temperature is always lower than for the other layers shown in Figure 1 . The lower temperature reduces the ionic conductivity of the electrolyte and increases the activation polarization of the electrodes. The performance of all cells was stable with clean-syngas for an operation time of 2 hours. After the test with clean-syngas, a mixture of $\mathrm{H}_{2} / \mathrm{N}_{2}$ was applied at the anode side for one hour under OCV and an I-V curve was recorded for electrochemical characterization. As shown in Table II, the cell voltages show almost identical values at $0.25 \mathrm{~A} / \mathrm{cm}^{2}$ before and after clean-syngas test. The syngas with tars (with removed sulfur and chlorine, but tar reformer bypassed; called tar-syngas from here on) was then applied to the stack. Before the test, the tar species were identified through the solid phase 


\begin{tabular}{|c|c|c|c|}
\hline & Before test & After clean-syngas test & After tar-syngas \\
\hline Cell 1 & $0.834 \mathrm{~V}$ & $0.839 \mathrm{~V}$ & $0.804 \mathrm{~V}$ \\
\hline Cell 2 & $0.921 \mathrm{~V}$ & $0.922 \mathrm{~V}$ & $0.912 \mathrm{~V}$ \\
\hline Cell 3 & $0.918 \mathrm{~V}$ & $0.919 \mathrm{~V}$ & $0.914 \mathrm{~V}$ \\
\hline Cell 4 & $0.916 \mathrm{~V}$ & $0.917 \mathrm{~V}$ & $0.906 \mathrm{~V}$ \\
\hline
\end{tabular}

adsorption (SPA) method ${ }^{34}$ as total content of $3.5 \mathrm{~g} / \mathrm{Nm}^{3}$ including benzene, toluene, phenol, naphthalene, $\mathrm{m}$-cresol, and minor traces of undefined tars as shown in Table I. In the tar-syngas test, cell 1 shows again lower initial voltage than the others as same manner in cleansyngas test. Cell 1 also shows higher degradation than the other cells after test in I-V curve under dry hydrogen (see Table II). The cell power output was about $2.5 \%$ lower at $0.25 \mathrm{~A} / \mathrm{cm}^{2}$ under dry hydrogen compared to the power output before test under same conditions, while the other cells show about $1 \%$ lower power. The power loss was not high, but it is a considerable value in the short operation time of only about $5 \mathrm{~h}$. The test was terminated since an increase of the pressure drop across the stack triggered an overpressure-safety valve in the gas supply line to open.

Macroscopic.-Figure 3 shows optical photographs of cells with frames and interconnects after test and disassembly. In Figure 3a, the entire cell No. 1 with gas manifolds and the whole frame and from the other three layers only the fuel-in manifold areas of the cells are presented. All four cells show heavy carbon deposition on the support surface near the fuel inlet. Since carbon deposition was not observed after stack operation using syngas with the tar removed (see supplementary Figure S1), the tar is estimated as the cause of carbon deposition. This carbon deposition was more pronounced at the edge of the cells. Another visible change of the cell is a discoloration on the support surface downstream from the area where carbon was deposited (more light gray). The image of cell 1 appears slightly different since all carbon powder was removed for micro structure analysis. Figure $3 \mathrm{~b}$ shows the photo of an interconnect in the stack with Ni mesh current collector. Similar to what is observed in the cells, carbon deposition is also observed on the Ni mesh near the area of the fuel inlet. It is obvious that $\mathrm{Ni}$ plays the role of catalyst for carbon formation since there was no carbon deposited on the stainless steel interconnect surface. Carbon deposition in the Ni meshes was found in each layer. Figure $3 \mathrm{c}$ shows cross section optical microscope image of the mesh structure. A clear boundary as observed between carbon (darker area) and polymer resin (brighter area) which was used for sample preparation. The carbon deposition shows thick and dense structure which seems to be enough to hinder the fuel gas flow and cause the pressure drop of the stack. Additionally, both, cell frame and interconnect show discoloration near the fuel inlet area. It is estimated to be a Cr- and Mn-oxide scale, which appears after test with not only hydrocarbon fuel but also pure hydrogen. Therefore, this discoloration seems to be not a result of tar addition in the fuel, but the oxidation behavior of the interconnect material itself.

Carbon deposition and microstructural changes.-From the cell photographs, the cell support surface shows two visible changes: carbon deposition and discoloration. For the microstructural analysis, SEM is used at three different areas: optically unchanged area (1), discolored area (2), and the area with accumulated carbon (3), which are indicated in Figure 3. SEM images of these areas are presented in Figure 4 with different magnifications. The unchanged area image (Figure 4a) shows a typical Ni/YSZ anode surface morphology. On the other hand, the SEM image of discolored area (Figure 4b) shows structural changes that include the loss of connectivity between parti-
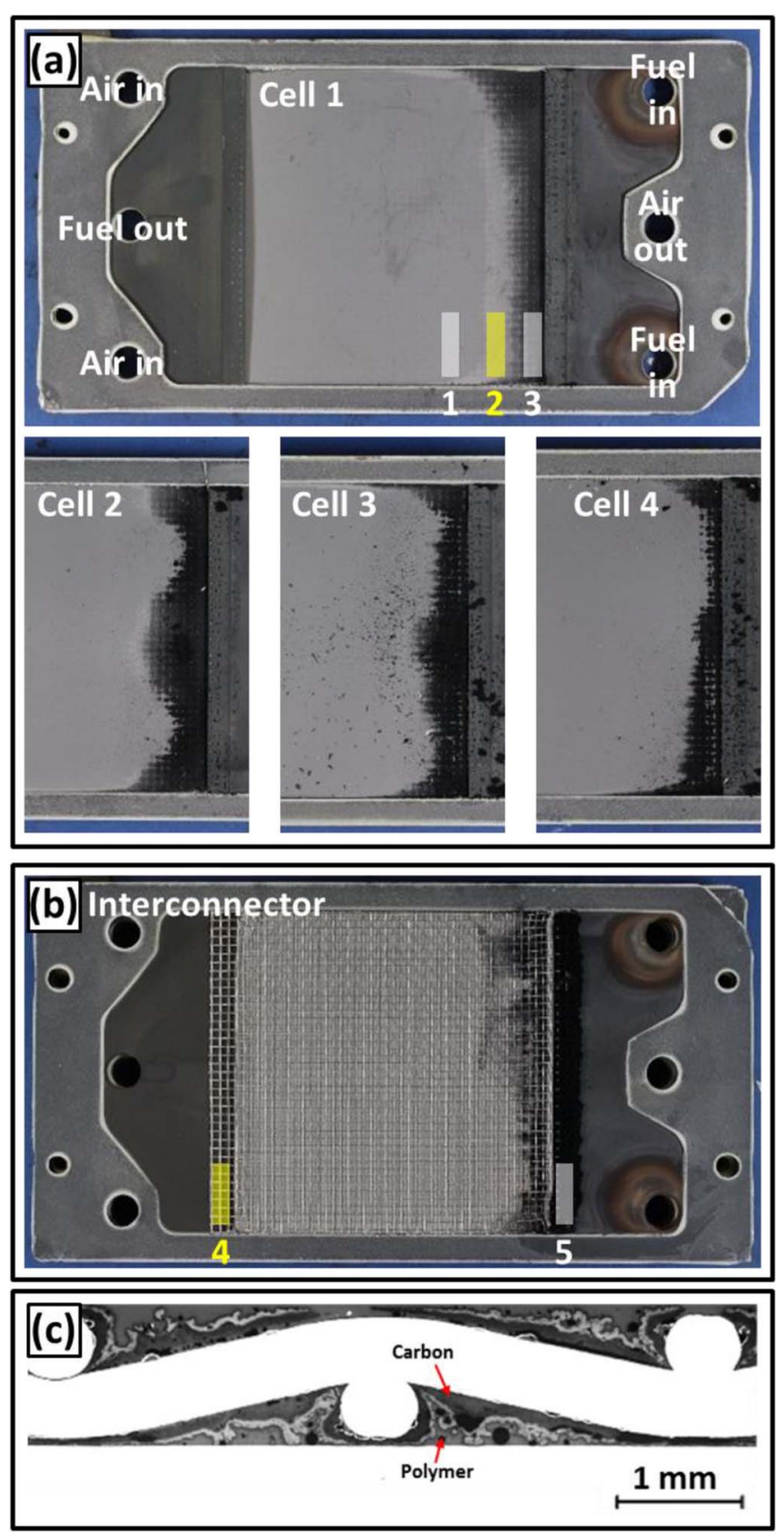

Figure 3. The photo of cells with frame (a) and interconnect (b) after stack disassembly, and optical microscope of contacting Ni mesh (c).

cles, as well as seemingly coarsened particle sizes. A similar result of structural changes and discoloration of the anode support was reported in a previous study about single cell tests with phenol in simulated syngas. ${ }^{35,36}$ The SEM image of the area with strong carbon deposition (Figure 4c) shows a complete surface coverage by carbon fibers. Several studies reported similar results of carbon-fiber formation in the anode or anode support after dry hydrocarbon fuel tests, ${ }^{16,37,38}$ but it is unusual in steam reforming tests, especially with such heavy surface deposition. As shown in the high magnification images of the carbon fibers, Ni particles were also observed at the tip of carbon fibers. This type of carbon growth has been reported in studies of methane reforming with a Ni catalyst. ${ }^{39-41}$ The size of the Ni particle at the tip of the fibers was significantly reduced compared to initially.

Figure 5 shows polished cross-sectional SEM images of the anode support and their EDX element mapping images for $\mathrm{Ni}$ and $\mathrm{Zr}$ (representing YSZ). The image of the unchanged area in Figure 5a 

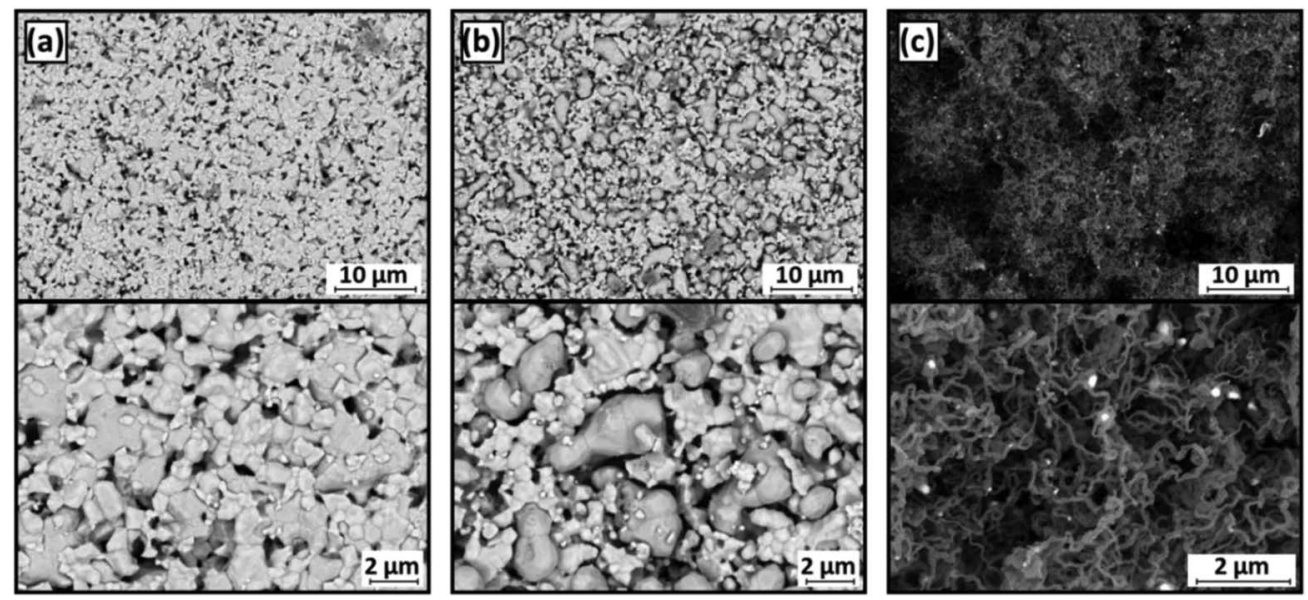

Figure 4. Surface SEM images of anode support with low (upper images) and high (below images) magnification from different positions, the figure labels (a), (b), and (c) are correspond with the area of 1,2, and 3 in Figure 3.

(area 1 in Figure 3) shows a porous Ni/YSZ microstructure with strong connectivity between particles. The EDX mapping images show a relatively homogeneous distribution of both $\mathrm{Ni}$ and YSZ particles. The discolored area in Figure 5b (area 2 in Figure 3) shows a different microstructure compared with the unchanged microstructure of the sample displayed in Figure 5a. It shows less connectivity between particles, with a large amount of pores (dark area). The discoloration can be explained by a change in the optical reflectivity through a roughening of the surface. Structural changes are mainly caused by a coarsening of the Ni particles as shown in Figure 5b, while there was no considerable change in the YSZ microstructure. The microstructure in the area showing heavy carbon deposition (area 3 in Figure 3) is presented in Figure 5c. In the cross-section, carbon deposition on the material surface is not visible since a carbon-based polymer resin was used for sample embedding, which is almost indistinguishable from the carbon deposited during the stack test. However, the thickness of the carbon deposition layer is estimated to about 40 to $50 \mu \mathrm{m}$ by the distribution of $\mathrm{Ni}$ and YSZ particles which are detached from the support. These detached particles in the deposited carbon layer indicate that the carbon has not simply accumulated on the support surface, but is caused by interaction with Ni and/or YSZ. The EDX mapping images show a smaller quantity of Ni than YSZ and reduced size of Ni particles compared to the unchanged image (corresponding with Ni particles at the tip of carbon fibers in Figure 4c). It seems then that $\mathrm{Ni}$ acts as catalyst for carbon fiber growth and the connecting Ni network is disintegrated in to loose particles which is defined in literature as metal dusting behavior, ${ }^{42-44}$ while YSZ particles were physically pushed away from the support by carbon fiber growth, the YSZ particles do not show any changes of size or shape.

Figure 6 shows SEM images of the contacting Ni mesh between cell anode supports and interconnect. The clean Ni mesh images of Figure $6 a$ were taken from area 4 in Figure 3 as a reference. It shows smooth surface without any secondary phase or dirt particles. In the case of the carbon covered Ni mesh (Figure 6b), loose carbon was removed by compressed air before SEM observation because the carbon structure was too thick to allow observation of the Ni mesh surface. The surface image shows carbon deposition and blister formation on the Ni mesh surface and the high magnification image shows distribution of tiny Ni particles, indicative of metal dusting behavior ${ }^{42-44}$ similar as observed in the anode support. These changes are significant considering the short-term test period of $5 \mathrm{~h}$. Figure $6 \mathrm{c}$ shows cross sectional image of single wire of the contacting Ni mesh. The image shows the delamination of the outer part of the wire as a layer which is corresponded with blisters in Figure 6b. The high magnification Ni EDX mapping image of single wire shows not only layered delamination but also small $\mathrm{Ni}$ particle detachment from wire surface.

Raman spectroscopy on the cell.-Raman micro-spectroscopy was applied to a fractured cell to examine the carbon deposition throughout the support and anode layers. A small piece of sample was taken from heavy carbon deposited area of Cell 2 for the measurement as a representative area. Figure 7a shows a mapping of the carbon distribution in the fractured cross-section of the cell, taken through a mesh of Raman point measurements. Carbon deposition
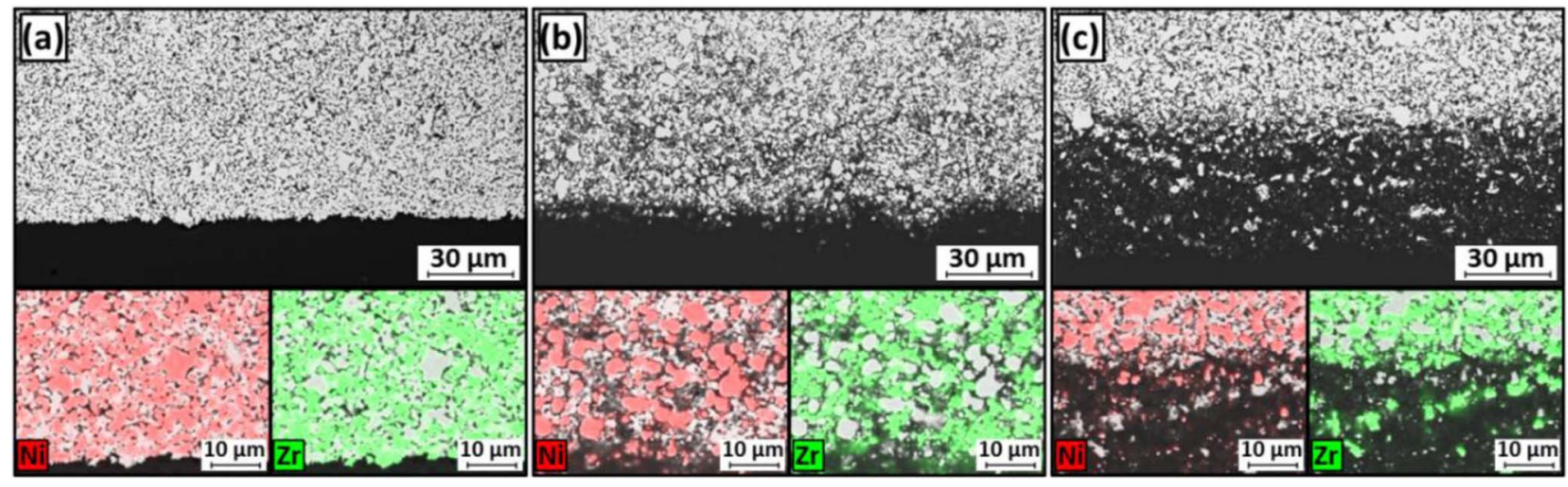

Figure 5. Polished cross sectional SEM images and EDX element mapping results of the cell supports, the figure labels (a), (b), and (c) are correspond with the area of 1,2, and 3 in Figure 3. 

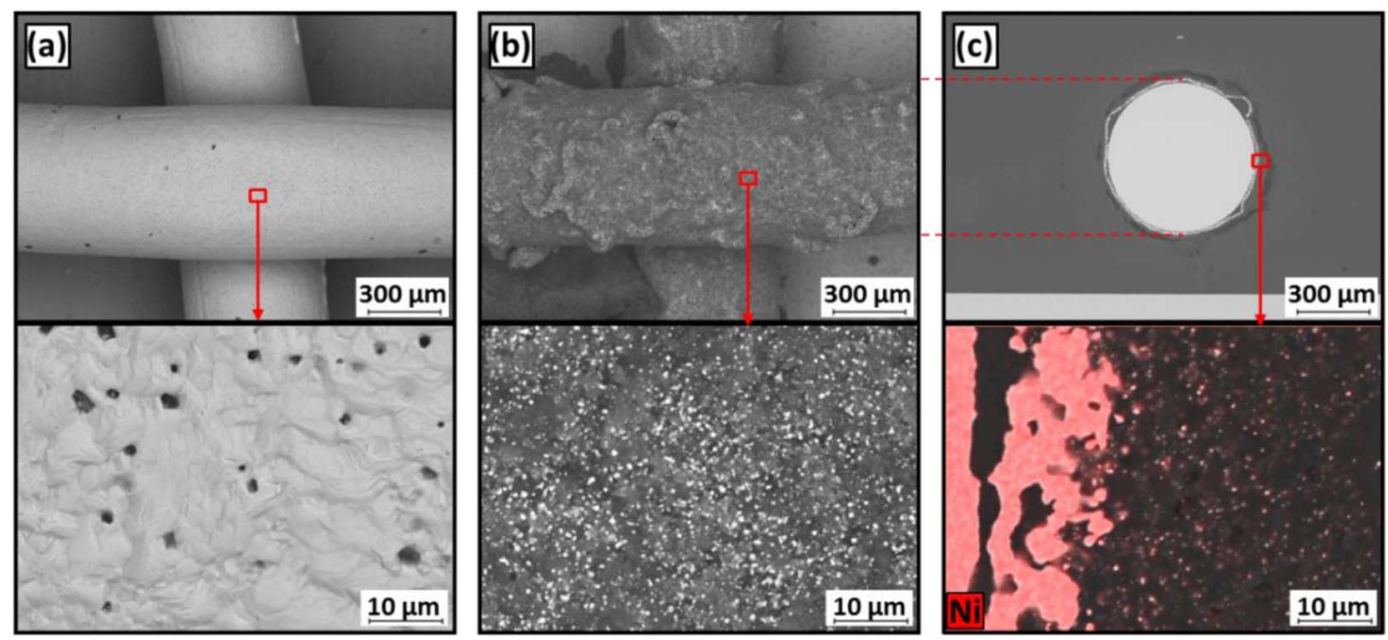

Figure 6. SEM images of contacting Ni mesh on the interconnect with low (upper images) and high (bottom images) magnification, the clean Ni mess image of (a) was achieved from the area 4 and carbon covered mesh images of (b) and (c) were achieved from area 5 in Figure 3.

is denoted as red color, and the brightness corresponds to the spectral intensity of the carbon signal. The result shows a high intensity of carbon deposition at the surface of the anode support and a considerable depth into the support covered with carbon, up to about $100 \mu \mathrm{m}$ deep inside of support. There are a few points of carbon signal in the area near the anode, but not in the anode layer itself. Figure $7 \mathrm{~b}$ shows SEM images of the fractured cross-section of the cell, taken from the anode layer and near the surface of the support. The anode layer shows the typical anode microstructure with clean particles, but the support shows small contamination and fibers, which cannot be observed in the support after a test with pure $\mathrm{H}_{2}$. However, no specific structure related to carbon could be found by SEM, despite the strong carbon signal obtained by Raman from the same area. It seems that the operation time was too short to form a visible carbon structure, and carbon is only deposited on the particle surface in a thin layer. Figure 7c shows Raman spectroscopy of carbon powder which was achieved from the surface of anode support and Ni mesh. The Raman result shows spectra pattern of the D band at $1350 \mathrm{~cm}^{-1}, \mathrm{G}$ band at $1580 \mathrm{~cm}^{-1}$, D' band at $1620 \mathrm{~cm}^{-1}, 2 \mathrm{D}$ band at $2700 \mathrm{~cm}^{-1}$, and $\mathrm{D}+\mathrm{G}$ band at $2940 \mathrm{~cm}^{-1}$. The D and D' bands are induced by disordered carbon species such as amorphous carbon (D band) and nano-crystalline graphite (D' band), the G band on the other hand is induced by graphene or layered graphene structure (graphite, carbon nanotube, and carbon fiber). ${ }^{45}$ The $2 \mathrm{D}$ band is an overtone of the $\mathrm{D}$ band and $\mathrm{D}+\mathrm{G}$ band is a combination of $\mathrm{D}$ and $\mathrm{G}$ bands. The Raman result indicates that the carbon grows as both ordered and disordered structure during the operation. The ordered carbon was already shown in Figure $4 \mathrm{c}$ as carbon fibers, while the disordered carbon species cannot easily be detected by SEM. It is clearly shown in the Figure 7c that the carbon powder from $\mathrm{Ni}$ mesh has more disordered structure

S: support, A: anode, E: electrolyte

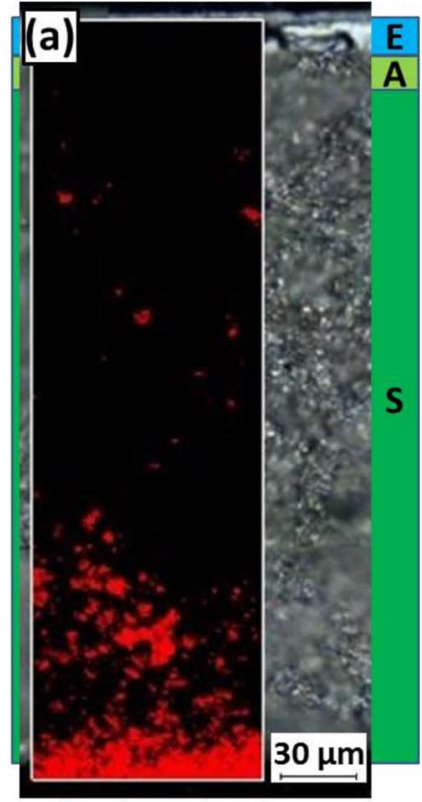

- Carbon distribution
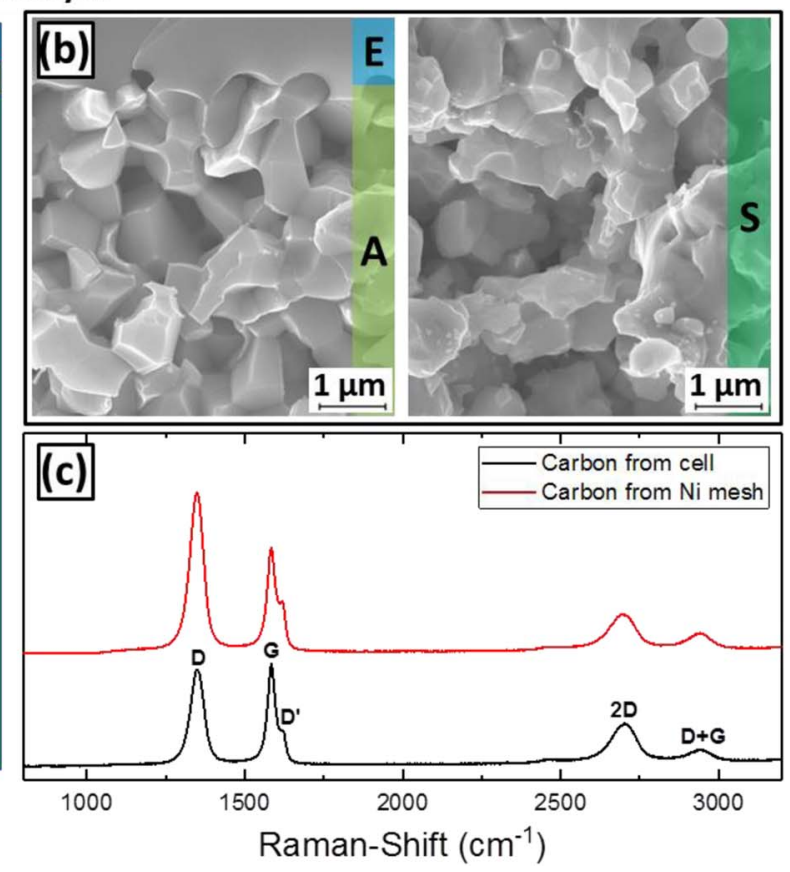

Figure 7. Carbon distribution mapping result of fractured cell cross section by Raman spectroscopy (a), SEM images of fractured cell cross section (b), and Raman shift result of carbon from cell surface and contacting Ni mesh (c). 
than carbon on the support. It seems that the Ni particle size governs the carbon growth: the small Ni particles are more suitable for one directional (ordered) carbon growth like tubes and fibers, but bulk wire does not.

\section{Discussion}

It is well known that the carbon deposition is possible without tar when the syngas has too low steam to carbon ratio. ${ }^{46,47}$ However, syngas composition in this study shows a $\mathrm{C}-\mathrm{H}-\mathrm{O}$ ratio that does not favor carbon formation according to thermodynamic calculations. ${ }^{48}$ As a confirmation, no carbon deposition could be observed on the stack run on syngas with the gas cleaning system enabled (see supplementary Figure S1). Raman spectroscopy result did not detect carbon related spectra like D and G bands (see supplementary Figure S2), and the chemical analysis result shows a lower carbon content compared to the test using clean syngas (see supplementary Table S1). Since the tars were not removed but reformed, the tar-syngas has same $\mathrm{C}-\mathrm{H}-\mathrm{O}$ composition as clean-syngas. Therefore carbon deposition was not expected in the short time of stack operation. Additionally, the high steam content $\left(\sim 42 \% \mathrm{H}_{2} \mathrm{O}\right)$ facilitates tar 1 and $\mathrm{CH}_{4} 2$ steam reforming and the water gas shift (WGS) Reaction $3{ }^{49}$

$$
\begin{gathered}
\mathrm{C}_{\mathrm{x}} \mathrm{H}_{\mathrm{y}} \mathrm{O}_{\mathrm{z}}+(\mathrm{x}-\mathrm{z}) \mathrm{H}_{2} \mathrm{O} \rightarrow \mathrm{xCO}+(\mathrm{x}+\mathrm{y} / 2-\mathrm{z}) \mathrm{H}_{2} \\
\mathrm{CH}_{4}+\mathrm{H}_{2} \mathrm{O} \leftrightarrow \mathrm{CO}+3 \mathrm{H}_{2}\left(\mathrm{CH}_{4}\right. \text { steam reforming) } \\
\mathrm{CO}+\mathrm{H}_{2} \mathrm{O} \leftrightarrow \mathrm{CO}_{2}+\mathrm{H}_{2} \text { (water gas shift reaction) }
\end{gathered}
$$

Despite these expectations, the analysis of the stack after operation with tar-contaminated syngas yields the following observations:

i) Heavy carbon deposition was observed on the cell anode support and Ni mesh current collector after stack operation with tar containing syngas.

ii) The anode support shows micro structural changes (Ni coarsening and connectivity loss between particles) under and near the carbon deposition area, and Ni shows metal dusting at the support and contacting Ni mesh.

iii) Although the tar was supplied continuously, the carbon deposition and structure change were present in spatially confined area near to the fuel inlet.

iv) The heavy carbon deposition in the Ni mesh and Ni-YSZ support acted as a constriction of the free volume for gas transport. Since the flux stayed constant during the stack test, the pressure drop across the stack increased exponentially. Therefore, the stack test was terminated after $5 \mathrm{~h}$ of operation with tar-containing syngas due to the stack pressure drop.

v) The I-V characteristics after the test with tar-containing syngas (measured with dry hydrogen) show an I-V behavior associated with a diffusion polarization on the fuel side for cell 1 , which was found to have the strongest carbon deposition (see supplementary Figure S4). We suggest that the reason for this is the restricted gas flow on the fuel side due to the carbon deposition.

Clearly, the present investigation offers insufficient information to form a complete picture of the degradation mechanism. However, we suggest the following hypothesis for the observed scenario: when the tar species are first introduced into the syngas, they are chemisorbed on the support and anode material surface near the fuel inlet area. The tar chemisorption deactivates the catalytically active surface area of the Ni catalyst, such as the three phase boundaries (TPB). The coverage of the Ni mesh as well as the $\mathrm{Ni}$ in the support and anode depends on the rates of adsorption and desorption, as well as the rate of reforming. Especially benzene and naphthalene are reported as tars with slow reforming kinetics. ${ }^{50}$ Supporting cell tests using only one tar in simulated syngas have confirmed that while light tars like phenol are reformed in the support and do not affect the electrochemical performance (i.e. they do not reach the anode), ${ }^{35,36}$ poly-aromatic tars such as naphthalene and phenanthrene decrease the electrochemical performance already at much lower concentrations and are therefore not completely reformed in the support ${ }^{51,52}$ (see supplementary Figure S3). It is also evident from the cell tests that a large part of the strong electrochemical degradation observed for naphthalene is reversible, but the recovery is much slower than the degradation. This may be interpreted as evidence that the adsorption of heavy tars on the active $\mathrm{Ni}$ surface (resulting in electrochemical degradation due to blocked active sites) is much faster than the tar reforming reaction or tar desorption under the investigated conditions. Our hypothesis corresponds well to a study of Rostrup-Nielsen, who reports that irreversible adsorption to the $\mathrm{Ni}$ surface and slow reforming reactions occur for higher hydrocarbons, which is also accompanied by thermal cracking at temperature above $600-650^{\circ} \mathrm{C} .^{53}$

In such a scenario, the faster adsorption kinetics and the constant supply of tar lead to an accumulation of chemisorbed tar species close to the inlet area, which increases the carbon-to-steam ratio until the formation of carbon becomes thermodynamically favorable. ${ }^{48}$ This would explain why the carbon deposition is restricted to an area close to the inlet. In addition, the deterioration of the support structure (also observed in previous investigations ${ }^{35,36}$ ) leads to both a depletion of $\mathrm{Ni}$ in the inlet area and a coarsening of the Ni particles. This microstructural change results in a decreased active surface area of the $\mathrm{Ni}$ catalyst for tar reforming, and as a consequence, the poisoned area can slowly spread further into the cell.

A second possible effect of the microstructural deterioration affects the local cooling of the reaction zone through the endothermic tar reforming reaction. While the Ni network in the support is highly thermally conductive and therefore prevents significant, local cooling effects, the deterioration of the Ni network leads to isolated Ni particles (see Figure 4c). Without the high thermal conductivity of the $\mathrm{Ni}$ network, substantial local cooling may become possible, which in turn can be expected to enhance carbon deposition. This may explain why the carbon deposition is the heaviest in the region of the support that has deteriorated the strongest (see Figure 4).

The above hypotheses are directly related with carbon deposition behavior because these changes deactivate the steam reforming and WGS reaction. ${ }^{1-3}$ Therefore, solid carbon formation can be activated by such reactions of $\mathrm{CH}_{4}$ decomposition 4 and Boudouard Reaction $5 .{ }^{54}$

$$
\mathrm{CH}_{4} \leftrightarrow \mathrm{C}+2 \mathrm{H}_{2}\left(\mathrm{CH}_{4} \text { decomposition }\right)
$$

$$
2 \mathrm{CO} \leftrightarrow \mathrm{C}+\mathrm{CO}_{2} \text { (Boudouard reaction) }
$$

The rea where carbon deposition occurs leads to a hindrance of the fuel gas flow before significant cell degradation can be observed. For the bio-syngas fuel utilization, tar cleaning with pre-reformer seems essential in current Ni-YSZ based anode support and Ni mesh current collector.

\section{Summary}

We operated a planar 4 layer SOFC stack using wood bio-syngas fuel. The sulfur and chlorine was removed in bio-syngas, but tar species were remained. During the test, bottom cell shows lower performance and higher degradation behavior than others due to the lower actual temperature. Since the stack pressure drop increased during test, the test was terminated after 5 hour. There is massive and dense carbon deposition on the anode support and contacting Ni mesh, which is estimated to be the reason for pressure drop by hindrance of fuel gas flow. A structural change of the anode support surface was observed with carbon deposition and metal dusting of the $\mathrm{Ni}$ in the support and the contacting mesh. Although there was no significant performance degradation in short operation time, carbon deposition was detected not only on the surface but also inside the support by means of Raman spectroscopy. 


\section{Acknowledgments}

The present investigations are supported by Deutsche Forschungsgemeinschaft (DFG), which is gratefully acknowledged (SP 367/5-1 (TUM) and ME 4283/2-1 (Jülich)). The authors thank Dr. D. Sebold for help with the SEM investigation, the colleagues from ZEA-1 for stack assembly and the colleagues in IEK-3 for stack implementation.

\section{ORCID}

Felix Fischer (1D https://orcid.org/0000-0002-9724-5965

Christian Lenser (B) https://orcid.org/0000-0001-5636-2201

Norbert H. Menzler (D) https://orcid.org/0000-0001-7091-0980

\section{References}

1. T. L. Skafte, J. Hjelm, P. Blennow, and C. R. Graves, Quantitative review of degradation and lifetime of solid oxide cells and stacks, in, p. 8, European Fuel Cell Forum (2016).

2. L. Blum, P. Batfalsky, Q. Fang, L. G. J. de Haart, J. Malzbender, N. Margaritis, N. H. Menzler, and R. Peters, J. Electrochem Soc, 162, F1199 (2015).

3. L. Blum, L. G. J. de Haart, J. Malzbender, N. Margaritis, and N. H. Menzler, AnodeSupported Solid Oxide Fuel Cell Achieves 70000 Hours of Continuous Operation, (2016).

4. L. Blum, P. Batfalsky, L. G. J. de Haart, J. Malzbender, N. H. Menzler, R. Peters, W. J. Quadakkers, J. Remmel, F. Tietz, and D. Stolten, Solid Oxide Fuel Cells 13 (Sofc-Xiii), 57, 23 (2013).

5. T. da Silva Veras, T. S. Mozer, D. da Costa Rubim Messeder dos Santos, and A. da Silva César, Int J. Hydrogen Energ, 42, 2018 (2017).

6. I. Dincer and C. Acar, Int J. Hydrogen Energ, 42, 14843 (2017).

7. R. G. Lemus and J. M. Martínez Duart, Int J. Hydrogen Energ, 35, 3929 (2010).

8. S. L. Douvartzides, F. A. Coutelieris, A. K. Demin, and P. E. Tsiakaras, AIChE Journal, 49, 248 (2004)

9. G. J. Saunders, J. Preece, and K. Kendall, Journal of Power Sources, 131, 23 (2004)

10. S. McIntosh and R. J. Gorte, Chem Rev, 104, 4845 (2004).

11. D. X. Cao, Y. Sun, and G. L. Wang, Journal of Power Sources, 167, 250 (2007)

12. K. D. Panopoulos, L. E. Fryda, J. Karl, S. Poulou, and E. Kakaras, Journal of Power Sources, 159, 570 (2006).

13. R. Suwanwarangkul, E. Croiset, M. D. Pritzker, M. W. Fowler, P. L. Douglas, and E. Entchev, Journal of Power Sources, 166, 386 (2007).

14. W. Doherty, A. Reynolds, and D. Kennedy, J. Electrochem Soc, 157, B975 (2010).

15. A. Di Carlo, E. Bocci, and V. Naso, Int J. Hydrogen Energ, 38, 532 (2013).

16. J. Mermelstein, M. Millan, and N. P. Brandon, Chem Eng Sci, 64, 492 (2009).

17. T. Namioka, T. Naruse, and R. Yamane, Int J. Hydrogen Energ, 36, 5581 (2011).

18. M. Liu, M. G. Millan, P. V. Aravind, and N. Brandon, J. Electrochem Soc, 158, B1310 (2011).

19. D. Papurello, A. Lanzini, P. Leone, and M. Santarelli, Renewable Energy, 99, 747 (2016).

20. D. Pumiglia, S. Vaccaro, A. Masi, S. J. McPhail, M. Falconieri, S. Gagliardi, L. Della Seta, and M. Carlini, Journal of Power Sources, 340, 150 (2017).

21. W. Doherty, A. Reynolds, and D. Kennedy, Journal of Power Sources, 277, 292 (2015).
22. D. Papurello, A. Lanzini, L. Tognana, S. Silvestri, and M. Santarelli, Energy, 85, 145 (2015).

23. A. Baldinelli, G. Cinti, U. Desideri, and F. Fantozzi, Energy Conversion and Management, 128, 361 (2016).

24. Z. Cheng, H. Abernathy, and M. Liu, The Journal of Physical Chemistry C, 111, 17997 (2007).

25. K. Sasaki, K. Susuki, A. Iyoshi, M. Uchimura, N. Imamura, H. Kusaba, Y. Teraoka, H. Fuchino, K. Tsujimoto, Y. Uchida, and N. Jingo, J. Electrochem Soc, 153, A2023 (2006).

26. W. M. Harris, J. J. Lombardo, G. J. Nelson, B. Lai, S. Wang, J. Vila-Comamala, M. Liu, M. Liu, and W. K. S. Chiu, Sci Rep-Uk, 4, 5246 (2014).

27. W. Liu, X. Sun, O. Marina, L. Pederson, and M. Khaleel, in Advances in Materials Science for Environmental and Nuclear Technology II, (2011).

28. H. O. Finklea, W. Zhang, M. Jony, and B. Demirgok, J. Electrochem Soc, 162, F1101 (2015).

29. Z. Abu El-Rub, E. A. Bramer, and G. Brem, Industrial \& Engineering Chemistry Research, 43, 6911 (2004).

30. V. D. M. ThyssenKrupp, (2008).

31. X. Montero, F. Tietz, D. Sebold, H. P. Buchkremer, A. Ringuede, M. Cassir, A. Laresgoiti, and I. Villarreal, Journal of Power Sources, 184, 172 (2008).

32. S. M. Gross, D. Federmann, J. Remmel, and M. Pap, Journal of Power Sources, 196, 7338 (2011).

33. L. G. J. de Haart, J. Mougin, O. Posdziech, J. Kiviaho, and N. H. Menzler, Fuel Cells, 9, 794 (2009).

34. C. Brage, Q. Yu, G. Chen, and K. Sjöström, Fuel, 76, 137 (1997).

35. M. Geis, S. Herrmann, S. Fendt, H. Jeong, C. Lenser, N. H. Menzler, and H. Spliethoff, Int J. Hydrogen Energ, (2018).

36. H. Jeong, M. Geis, C. Lenser, S. Lobe, S. Herrmann, S. Fendt, N. H. Menzler, and O. Guillon, Int J. Hydrogen Energ, (2018).

37. B. Novosel, M. Marinšek, and J. Maček, Journal of Fuel Cell Science and Technology, 9, 061003 (2012)

38. D. Yoon and A. Manthiram, Energ Environ Sci, 7, 3069 (2014).

39. K. Otsuka, H. Ogihara, and S. Takenaka, Carbon, 41, 223 (2003).

40. Y. Li, B. Zhang, X. Xie, J. Liu, Y. Xu, and W. Shen, J. Catal, 238, 412 (2006).

41. K. Großmann, P. Treiber, and J. Karl, Int J. Hydrogen Energ, 41, 17784 (2016).

42. H. J. Grabke, R. Krajak, E. M. Müller-Lorenz, and S. Strauß, Materials and Corrosion, 47, 495 (1996).

43. J. Klöwer, H. J. Grabke, and E. M. Müller-Lorenz, Materials and Corrosion, 49, 328 (1998).

44. C. M. Chun, G. Bhargava, and T. A. Ramanarayanan, J. Electrochem Soc, 154, C231 (2007).

45. F. Rosenburg, E. Ionescu, N. Nicoloso, and R. Riedel, Materials, 11, 93 (2018).

46. Z.-R. Xu, X.-Z. Fu, J.-L. Luo, and K. T. Chuang, J. Electrochem Soc, 157, B1556 (2010).

47. V. Subotić, C. Schluckner, B. Stöckl, V. Lawlor, H. Schroettner, and C. Hochenauer, J. Electrochem Soc, 163, F1515 (2016).

48. Z. Jaworski, B. Zakrzewska, and P. Pianko-Oprych, Reviews in Chemical Engineering, 33 (2017)

49. J.-P. Cao, P. Shi, X.-Y. Zhao, X.-Y. Wei, and T. Takarada, Fuel Process Technol, 123 34 (2014).

50. T. B. Dörr, S. Schmidt, A. Drochner, and H. Vogel, Chemical Engineering \& Technology, 40, 351 (2017)

51. N. J. J. Dekker, J. P. P. Ouweltjes, and B. Rietveld, Ecs Transactions, 7, 1465 (2007)

52. M. Hauth, W. Lerch, K. König, and J. Karl, Journal of Power Sources, 196, 7144 (2011).

53. J. R. Rostrup-Nielsen, Physical Chemistry Chemical Physics, 3, 283 (2001).

54. L. Maier, B. Schädel, K. Herrera Delgado, S. Tischer, and O. Deutschmann, Top Catal, 54, 845 (2011). 